\title{
Resource Assessment of the Springfield, Herrin, Danville, and Baker Coals in the Illinois Basin
}

\section{Introduction}

This assessment provides overviews of the geologic setting, distribution, quantity, and quality of the major producing coals in the Illinois Basin. The coal-bearing rocks of the Illinois Basin are of Pennsylvanian age and underlie $36,800 \mathrm{mi}^{2}$ in Illinois, $6,500 \mathrm{mi}^{2}$ in Indiana, and 6,400 $\mathrm{mi}^{2}$ in western Kentucky. The major economic coals in the basin are the Springfield, Herrin, Danville, and Baker Coals.

The principal products of this assessment are:

A. Coal resource estimates categorized by State, mining district, county, geologic reliability of the estimate, and coal thickness and depth;

B. Regional and statewide maps that depict coal extent, thickness, elevation (structure), mined-out areas, areas where the coal may potentially be mined at the surface or underground, and geographic distributions of ash, sulfur, and major, minor, and trace-element contents; and

C. Digital databases that contain all publicly available pointsource data on coal thickness and depth (more than 40,000 records) and coal quality (more than 6,900 records).

This assessment was a cooperative effort between the U.S. Geological Survey and the State Geological Surveys of Illinois, Indiana, and Kentucky.

Stratigraphy-The Pennsylvanian rocks were deposited between about 325 and 290 million years before present. They reach a maximum thickness of nearly $2,500 \mathrm{ft}$ in southeastern Illinois and generally thin toward the north, northwest, and northeast. The Pennsylvanian rocks in the Illinois Basin are divided into the Raccoon Creek Group, Carbondale Formation or Group, and the McLeansboro Group. Figure 1 shows the relative stratigraphic positions of the Springfield, Herrin, Danville, and Baker Coals.

Structure-The major structural features in the Illinois Basin are the La Salle anticlinal belt, the DuQuoin monocline, and the Cottage Grove-Rough Creek fault system. These structures bound the Fairfield Basin in southeastern Illinois (fig. 2). In Illinois and Indiana, the major coals crop out along the margins of the basin and generally dip to depths of more than 1,000 ft at the center of the Fairfield Basin, as shown for the Springfield Coal in figure 2. In western Kentucky, structures affecting the coal-bearing rocks are different on either side of the east-west-trending Rough Creek fault system. North of the Rough Creek fault system, the rocks dip gently to the west at about $15-20 \mathrm{ft} / \mathrm{mi}$. South of the Rough Creek fault system, the structure is characterized by east-west-oriented synclines with much steeper dips, between 50 and $250 \mathrm{ft} / \mathrm{mi}$.

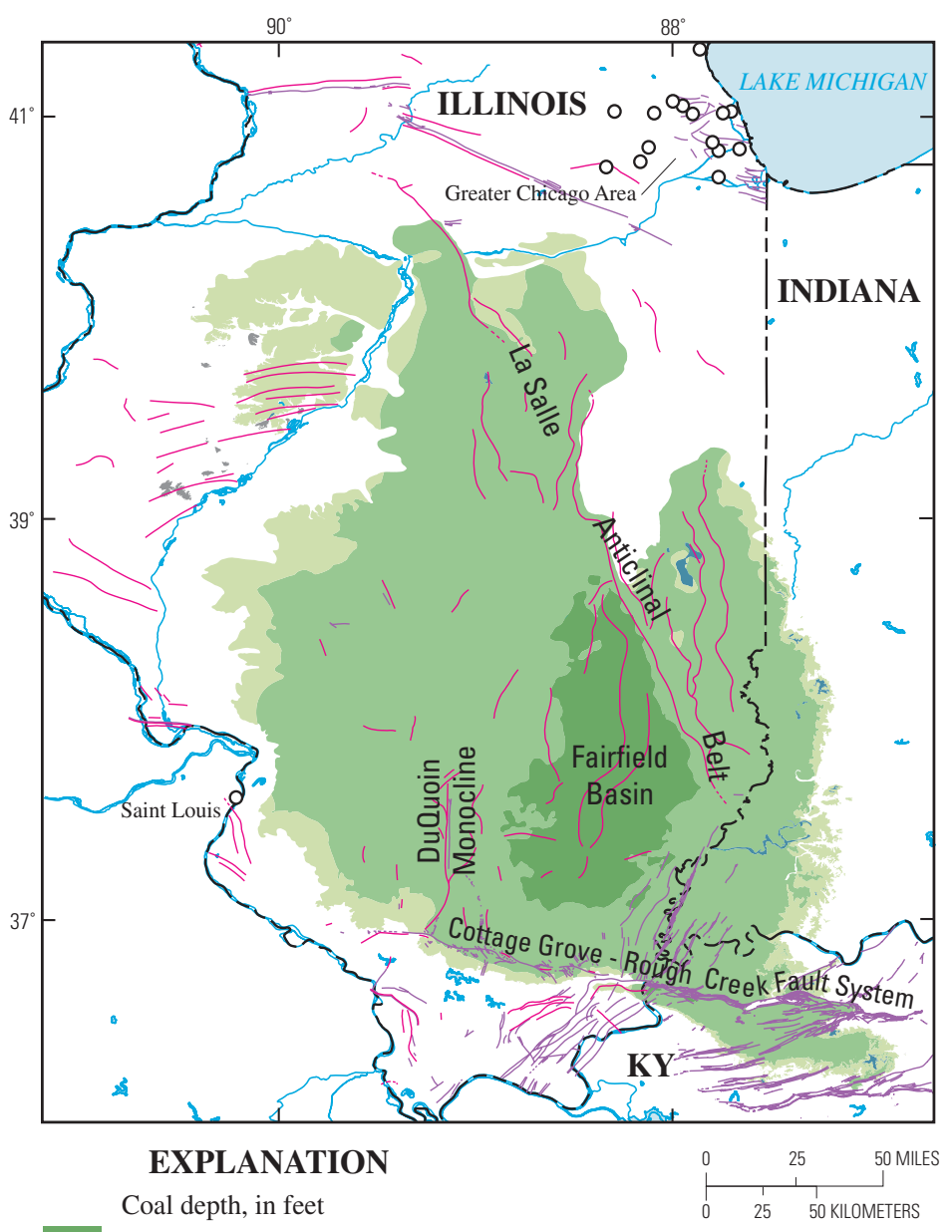

$>1,000$

$150-1,000$

$<150$

No coal

Unassessed

Anticline, syncline, or monocline

Fault

River, lake, or reservoir

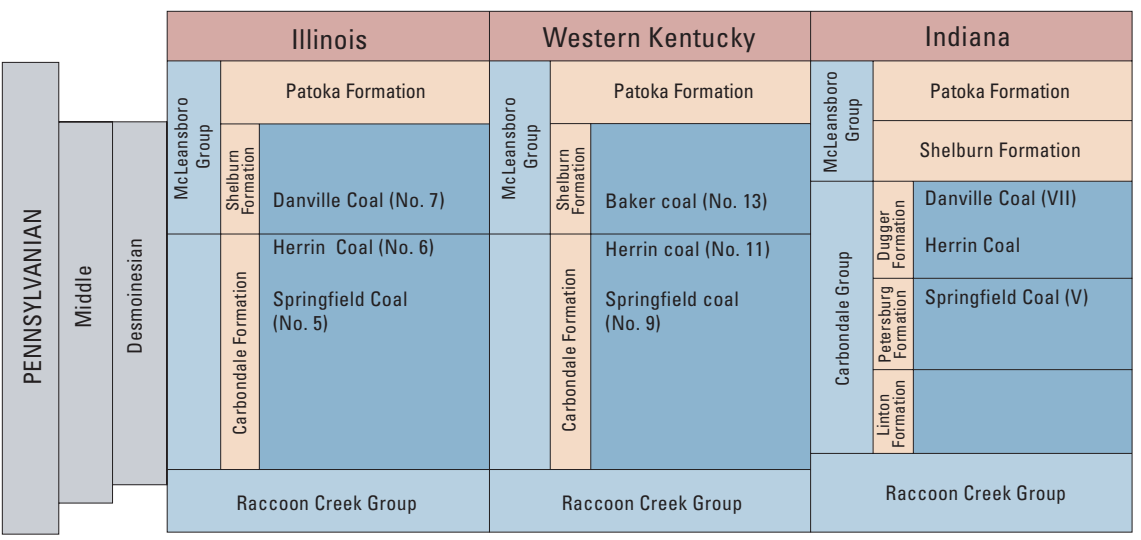

Figure 2 (above). Major structural features and extent and depth of the Springfield Coal in the Illinois Basin. Modified from Hatch and Affolter (2002, Chapter A, fig. 4).
Figure 1 (left). Generalized stratigraphic framework for the major producing coals in the Illinois Basin. Modified from Mastalerz and Harper (1998) and Greb and others (1992). 


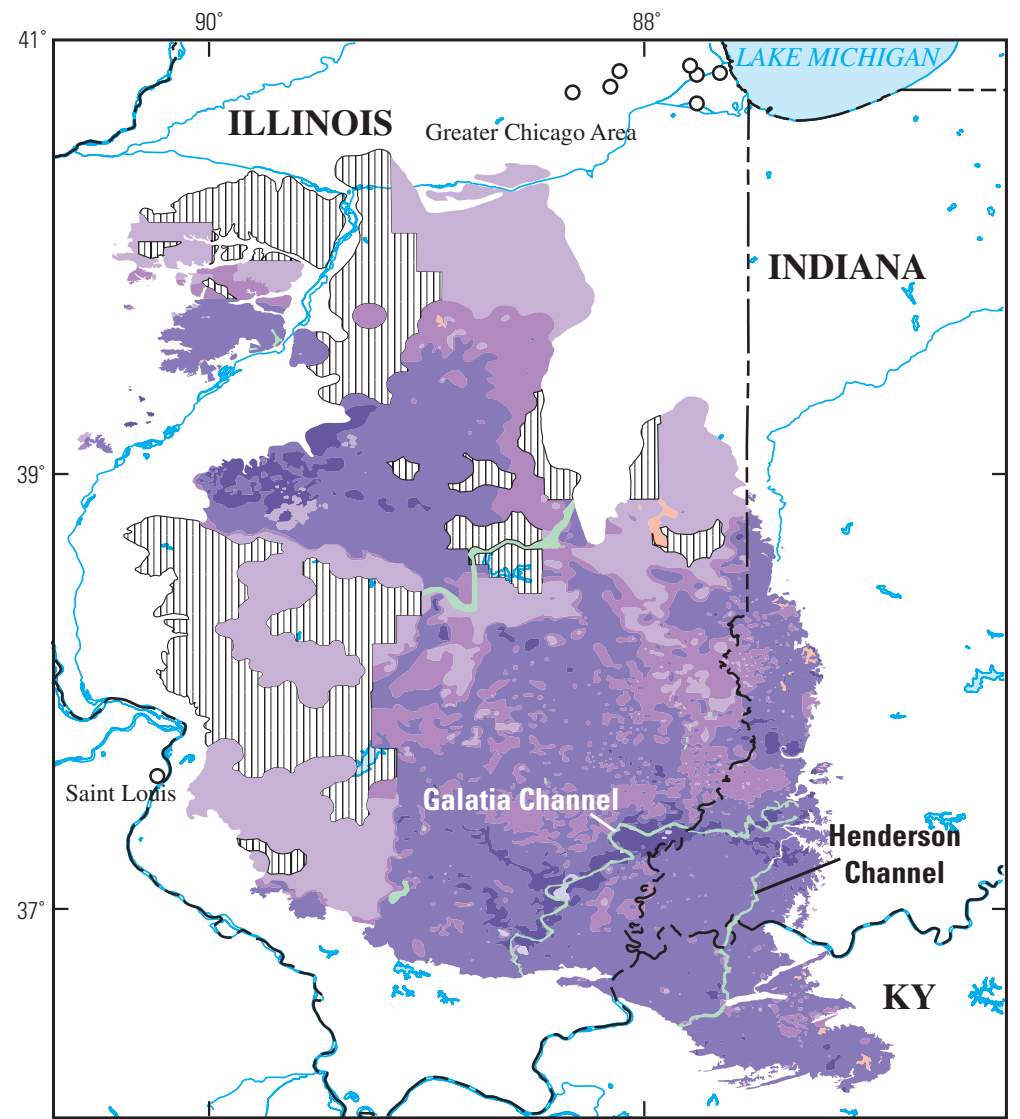

EXPLANATION

Thickness of coal, in inches

$>66$

$42-66$

$28-42$

$<28$

Coal split or thin coal

Channels or no coal

Insufficient data

Unassessed

River, lake, or reservoir

\section{Major Economic Coals}

Springfield Coal-The Springfield Coal is the most extensively mined coal in the Illinois Basin. In Illinois, this coal has a thickness of between 4.5 and $6 \mathrm{ft}$ in most areas where it has been mined. Thickness of the Springfield Coal (in inches) is shown in figure 3. In Indiana, coal thickness is usually between 3 and $7.4 \mathrm{ft}$, but as much as $13 \mathrm{ft}$ has been reported. South of the Rough Creek fault system in western Kentucky, the coal is 5-6 ft in thickness, but thins to less than $4 \mathrm{ft}$ toward the east and northeast of the Rough Creek fault system.

Herrin Coal-In Illinois, the Herrin Coal averages more than $6 \mathrm{ft}$ thick over extensive areas and locally reaches $15 \mathrm{ft}$ thick. It is thinner and irregular in thickness in much of central and southeastern Illinois. In Indiana, the Herrin is not well developed, and it is not mined. In western Kentucky, the Herrin occurs in two geographically distinct bodies. The thicker of these bodies is in a narrow belt along the south edge of the coal field, where the Herrin is as much as $10 \mathrm{ft}$ thick. Throughout the basin, the lower part of the Herrin Coal contains a prominent claystone parting (the "blue band") that normally is $1-3$ in. thick.

Danville and Baker Coals-In east-central Illinois, the Danville Coal is as much as $6 \mathrm{ft}$ thick. In most of the rest of the State, the Danville is thin, generally from a few inches to less than $3 \mathrm{ft}$ thick. In Indiana, the Danville ranges from 0.2 to 6 $\mathrm{ft}$ thick, averaging $4 \mathrm{ft}$ in the north and $2 \mathrm{ft}$ in the south. In western Kentucky, the Baker coal is a complex, multiple-bench zone in which mineable coals are separated by rock partings (Weisenfluh and others, 1998). The Danville Coal in southern Indiana is correlative to an upper bench of the Baker coal in western Kentucky. Two distinct bodies of thicker Baker coal are well documented-one south of the Rough Creek fault system and one north.

State and basin-wide maps showing the extent, depth, and thickness of the Herrin, Danville, and Baker Coals can be found in Chapters A, C, and D, and in the Arcview project in Hatch and Affolter (2002).

Figure 3 (left). Extent and thickness of the Springfield Coal in the Illinois Basin. Modified from Hatch and Affolter (2002, Chapter A, fig. 7).

Table 1. Estimated, remaining, identified resources of the Springfield, Herrin, Danville, and Baker Coals in Illinois, Indiana, and western Kentucky.

[Resource numbers are rounded to two significant figures, or to nearest 100 million tons for numbers greater than 10 billion short tons. Columns may not sum exactly due to rounding. NC, resources not calculated. Summarized from Hatch and Affolter (2002, Chapter D, Appendixes 1-3]

\begin{tabular}{|c|c|c|c|c|c|c|c|c|c|c|c|c|c|}
\hline \multirow{4}{*}{ Area } & \multirow{4}{*}{$\begin{array}{c}\text { Coal } \\
\text { depth } \\
\text { (feet) }\end{array}$} & \multicolumn{12}{|c|}{ Remaining, identified resources (million short tons) } \\
\hline & & \multirow{2}{*}{\multicolumn{4}{|c|}{$\begin{array}{l}\text { Springfield Coal } \\
\text { oal thickness (inches) }\end{array}$}} & \multirow{2}{*}{\multicolumn{4}{|c|}{$\begin{array}{c}\text { Herrin Coal } \\
\text { Coal thickness (inches) }\end{array}$}} & \multirow{2}{*}{\multicolumn{4}{|c|}{$\begin{array}{c}\text { Danville and Baker Coals } \\
\text { Coal thickness (inches) }\end{array}$}} \\
\hline & & & & & & & & & & & & & \\
\hline & & $14-28$ & $>28-42$ & $>42$ & All & $14-28$ & $>28-42$ & $>42$ & All & $14-28$ & $>28-42$ & $>42$ & All \\
\hline \multirow{3}{*}{ Illinois } & $0-150$ & 410 & 560 & 3,000 & 4,000 & 280 & & 5,900 & 7,600 & 910 & 880 & 630 & 2,400 \\
\hline & & 0 & 11,900 & 45,800 & 57,700 & 0 & 10,500 & 60,900 & 71,400 & 590 & 7,600 & 7,300 & 15,500 \\
\hline & & 410 & 12,500 & 48,800 & & 280 & 11,800 & 66,800 & 78,900 & 1,500 & & 8,000 & 17,900 \\
\hline \multirow{3}{*}{ Indiana } & & 25 & & & & $\mathrm{NC}$ & & $\mathrm{NC}$ & & 210 & & 500 & \\
\hline & $>150$ & 150 & 1,500 & 8,400 & 10,100 & $\mathrm{NC}$ & $\mathrm{NC}$ & $\mathrm{NC}$ & $\mathrm{NC}$ & 1,200 & 2,900 & 670 & 4,700 \\
\hline & Subtotal & 180 & 1,800 & 10,200 & 12,100 & $\mathrm{NC}$ & $\mathrm{NC}$ & $\mathrm{NC}$ & $\mathrm{NC}$ & 1,400 & 3,700 & 1,200 & 6,300 \\
\hline \multirow{3}{*}{$\begin{array}{l}\text { Western } \\
\text { Kentucky }\end{array}$} & & 1 & 17 & 960 & 980 & 47 & 74 & 430 & 550 & 310 & 360 & 260 & 930 \\
\hline & & 9 & 180 & 5,800 & 6,000 & 140 & 460 & 1,500 & 2,100 & 580 & 500 & 1,300 & 2,400 \\
\hline & Subtotal & 10 & 200 & 6,800 & 7,000 & 180 & 530 & 1,900 & 2,600 & 890 & 870 & 1,600 & 3,400 \\
\hline Total & & 430 & 860 & 5,700 & 7,000 & 320 & 1,400 & 6,300 & 8,100 & 1,400 & 2,100 & 1,400 & 4,900 \\
\hline Illinois & $>150$ & 160 & 13,500 & 60,000 & 73,700 & 140 & 11,000 & 62,400 & 73,500 & 2,300 & 11,000 & 9,200 & 22,500 \\
\hline Basin & Total & 590 & 14,400 & 65,700 & 80,700 & 460 & 12,400 & 68,700 & 81,600 & 3,700 & 13,100 & 10,600 & 27,400 \\
\hline
\end{tabular}




\section{Coal Resource Assessment}

Coal Production-Coal production in Illinois Basin began in the early 1800's. From 1890 to 1998, about 5,600 million short tons (mst) of coal were produced from all mineable coals in Illinois, about 2,500 mst in western Kentucky, and about 2,100 mst in Indiana. A maximum of about $148 \mathrm{mst}$ was produced from the basin in 1984. In 2000, coal production from the Illinois Basin was about 88.4 mst.

Remaining Coal Resources-For this assessment, estimated remaining coal resources are categorized by coal, State, mining area, county, overburden thickness $(0-150 \mathrm{ft}$ and $>150 \mathrm{ft})$, coal thickness (14-28 in., >28-42 in., and >42 in.), and reliability of estimate (Hatch and Affolter, 2002, Chapter D, Appendixes 1-3). For Illinois and Indiana, reliability categories are I-A ( $0-0.5 \mathrm{mi}$ from a data point), I-B $(>0.5-2 \mathrm{mi})$, and II-A ( $>2-4 \mathrm{mi})$. For western Kentucky, the categories are measured $(0-0.25 \mathrm{mi}$ from a data point), indicated $(>0.25-0.75$ $\mathrm{mi})$, inferred $(>0.75-3.0 \mathrm{mi})$, and hypothetical $(>3 \mathrm{mi})$. The remaining identified resources (reliability categories I-A + I-B + II-A or measured + indicated + inferred) categorized by coal, coal depth, and coal thickness for each State and for the basin are tabulated in table 1.

Resource quantities tabulated in table 1 can be summarized as follows:

A. For the Springfield Coal, remaining, identified resources in deposits $>42$ in. thick and at depths of $0-150 \mathrm{ft}$ (potentially surface mineable) are about 5.7 billion short tons (bst). For depths $>150 \mathrm{ft}$ (potentially mineable by underground methods), resources are about 60 bst. As an example, areas where the Springfield Coal is at depths of $0-150 \mathrm{ft}$ and $>150 \mathrm{ft}$ are shown in figure 2.

B. For the Herrin Coal, remaining, identified resources in deposits $>42$ in. thick and at depths of $0-150 \mathrm{ft}$ are about $6.3 \mathrm{bst}$; for depths $>150 \mathrm{ft}$, they are about $62.4 \mathrm{bst}$.

C. For the Danville and Baker Coals, remaining, identified resources in deposits $>42$ in. thick and at depths of $0-150 \mathrm{ft}$ are about $1.4 \mathrm{bst}$; for depths $>150 \mathrm{ft}$, they are about $9.2 \mathrm{bst}$.

D. For the Springfield, Herrin, Danville, and Baker Coals, total remaining, identified resources in deposits $>42$ in. thick are estimated at 145 bst.

Coal Availability-Coal resources available for mining are often significantly less than the original coal resource because coal has been mined, or because the coal resource is unavailable due to landuse or technological restrictions. Examples of land-use restrictions include cities, national forests, major roads, or cemeteries. Examples of technological restrictions include areas where the coal is $<42$ in. thick, or where the interburden between beds is too thin.

Cooperative studies by the USGS and the State Geological Surveys show that for nineteen selected 7.5-minute quadrangles in Illinois, 46 percent (4.6 bst) of the original coal resource (Springfield, Herrin, Danville, and two other coals) is available for mining. For ten selected 7.5-minute quadrangles in Indiana, 57 percent $(3.3 \mathrm{bst})$ of the
Table 2. Summary of coal availability for nineteen 7.5-minute quadrangles in Illinois, ten 7.5-minute quadrangles in Indiana, and twelve 7.5-minute quadrangles in western Kentucky.

[Resource numbers are rounded to two significant figures (modified from Hatch and Affolter, 2002, Chapter A, table 3]

\begin{tabular}{|c|r|r|r|r|}
\cline { 2 - 5 } \multicolumn{1}{c|}{} & \multicolumn{4}{c|}{ Coal resources (billion short tons) } \\
\hline Resource Category & Illinois & Indiana & $\begin{array}{c}\text { Western } \\
\text { Kentucky }\end{array}$ & \multicolumn{1}{c|}{ Total } \\
\hline Original & 10.0 & 5.8 & 5.1 & 21.0 \\
\hline Mined-out & 0.7 & 0.7 & 1.0 & 2.4 \\
\hline Land-use restrictions & 0.8 & 0.3 & 0.2 & 1.3 \\
\hline Technological restrictions & 3.9 & 1.5 & 1.3 & 6.7 \\
\hline Available & 4.6 & 3.3 & 2.7 & 11.0 \\
\hline
\end{tabular}

original coal resource (Springfield, Danville, and three other coals) is available, and for twelve selected 7.5-minute quadrangles in western Kentucky, 53 percent (2.7 bst) of the original coal resource (Springfield, Herrin, Baker, and two other coals) is available (table 2).

A statewide study of the availability of the Springfield Coal in Illinois (Treworgy and others, 1999) demonstrated that of an original resource of 52 bst of coal, in deposits $>42$ in. thick, about 57 percent (30 bst) is available or conditionally available for mining. Four percent ( 2.2 bst) is not available because it has been mined-out, 5 percent (2.5 bst) is not available because of land-use restrictions, and 34 percent (18 bst) is not available because of technological restrictions. Less than 1 percent $(0.5 \mathrm{bst}$ ) of the Springfield Coal resource lies beneath public lands.

Coal Quality-Statistical summaries of calorific value, ash yield, and total sulfur, arsenic, and mercury contents for the Springfield, Herrin, Danville, and Baker Coals are listed in table 3. Statistical summaries for 14 additional coal characterization parameters and for 36 other major, minor, and trace-element contents in these coals are listed in Hatch and Affolter (2002, Chapter E, Appendixes 2 and 3). Table 3 shows that ash yields, calorific values, total sulfur, arsenic, and mercury contents of these coals have similar statistics. Most other coal characterization parameters (such as fixed carbon, volatile matter, forms of sulfur and ash fusion temperatures) and elemental compositions (such as nitrogen, lead, uranium, antimony) are also similar for these coals. Geographic distributions and contents of 16 coal characterization measures and element contents for each coal can be found in Hatch and Affolter (2002, Chapter E, Appendix 7). An example of these distributions, mercury contents in the Springfield Coal, is shown in figure 4.

Table 3. Means and ranges of ash yield, calorific value, and total sulfur, arsenic, and mercury contents for the Springfield, Herrin, Danville, and Baker Coals in the Illinois Basin.

[Summary data are on a whole-coal, as-received basis; ppm, parts per million; n, number of analyses. Summarized from Hatch and Affolter (2002, Chapter E, Appendixes 2 and 3]

\begin{tabular}{|c|c|c|c|c|c|c|c|c|c|c|}
\hline \multirow[t]{2}{*}{ Coal } & \multicolumn{2}{|c|}{$\begin{array}{l}\text { Ash yield } \\
\text { (percent) }\end{array}$} & \multicolumn{2}{|c|}{$\begin{array}{l}\text { Calorific value } \\
\text { (Btu/pound) }\end{array}$} & \multicolumn{2}{|c|}{$\begin{array}{l}\text { Total sulfur } \\
\text { (percent) }\end{array}$} & \multicolumn{2}{|c|}{$\begin{array}{c}\text { Arsenic } \\
\text { (ppm) }\end{array}$} & \multicolumn{2}{|c|}{$\begin{array}{l}\text { Mercury } \\
\text { (ppm) }\end{array}$} \\
\hline & Mean & Range & Mean & Range & Mean & Range & Mean & Range & Mean & Range \\
\hline Springfield & 11.2 & $\begin{array}{c}2.8-49.7 \\
n=1,832\end{array}$ & 11,280 & $\begin{array}{c}4,810-13,910 \\
n=1,770\end{array}$ & 3.5 & $\begin{array}{c}0.5-19.5 \\
n=1,830\end{array}$ & 12 & $\begin{array}{c}0.27-130 \\
n=145\end{array}$ & 0.12 & $\begin{array}{c}<0.01-1.2 \\
n=123\end{array}$ \\
\hline Herrin & 10.9 & $\begin{array}{c}2.4-43.6 \\
n=2,542\end{array}$ & 11,170 & $\begin{array}{c}5,770-13,420 \\
n=2,390\end{array}$ & 3.0 & $\begin{array}{c}0.3-14.5 \\
n=2,517\end{array}$ & 6 & $\begin{array}{c}<0.2-140 \\
n=216\end{array}$ & 0.12 & $\begin{array}{c}<0.01-0.70 \\
n=206\end{array}$ \\
\hline $\begin{array}{l}\text { Danville and } \\
\text { Baker }\end{array}$ & 11.9 & $\begin{array}{l}4.4-44.2 \\
n=334\end{array}$ & 10,920 & $\begin{array}{c}5,800-12,990 \\
n=295\end{array}$ & 2.9 & $\begin{array}{l}0.3-9.7 \\
n=335\end{array}$ & 19 & $\begin{array}{c}0.50-70 \\
n=39\end{array}$ & 0.11 & $\begin{array}{c}<0.01-0.32 \\
n=39\end{array}$ \\
\hline
\end{tabular}




\section{Selected References}

Cady, G.H., 1935, Classification and selection of Illinois coals: Illinois State Geological Survey Bulletin 62, 354 p.

Cady, G.H., 1952, Mineable coal reserves of Illinois: Illinois State Geological Survey Bulletin 78, 138 p.

Currens, J.C., 1986, Coal-quality data for the western Kentucky coal field: Kentucky Geological Survey Open-File Report, Series $\mathrm{XI}, 40 \mathrm{p}$.

Gluskoter, H.J., Ruch, R.R., Miller, W.G., Cahill, R.A., Dreher, G.B., and Kuhn, J.K., 1977, Trace elements in coalOccurrences and distribution: Illinois State Geological Survey Circular 499, $154 \mathrm{p}$.

Greb, S.F., Williams, D.A., and Williamson, A.D., 1992, Geology and stratigraphy of the western Kentucky coal field: Kentucky Geological Survey Bulletin 1, Series XI, 77 p.

Hasenmueller, W.A., 1994, The quality of Indiana's coal resources: Indiana Geological Survey Occasional Paper 63, 45 p.

Hatch, J.R., and Affolter, R.H., eds., 2002, Resource assessment of the Springfield, Herrin, Danville, and Baker Coals in the Illinois Basin: U.S. Geological Survey Professional Paper 1625-D, 2 CD ROMs (Chapters A-E and Interactive ArcView project).

Mastalerz, M.D., and Harper, Denver, 1998, Coal in Indiana-A geologic overview: Indiana Geological Survey Special Report $60,45 \mathrm{p}$.

Spencer, F.D., 1953, Coal resources of Indiana: U.S. Geological Survey Circular 266, $42 \mathrm{p}$.

Smith, G.E., and Brant, R.A., 1980, Western Kentucky coal resources: Lexington, Ky., University of Kentucky Institute for Mining and Minerals Research, Energy Resource Series, 148 p.

Treworgy, C.G., Korose, C.P., Chenowith, C.A., and North, D.L., 1999, Availability of the Springfield Coal for mining in Illinois: Illinois State Geological Survey Illinois Mineral Note 118, 43 p.

Weisenfluh, G.A., Andrews, W.A., and Hiett, K.K., 1998, Availability of coal resources for the development of coalWestern Kentucky summary report: Kentucky Geological Survey Interim Report for U.S. Department of Interior Grant 14-08-001-A0896, $32 \mathrm{p}$.

\section{For further information on Illinois Basin coal resources contact:}

Joe Hatch, U.S. Geological Survey

Phone: 303-236-5418; jrhatch@usgs.gov

Russ Jacobson, Illinois State Geological Survey

Phone: 217-244-2426; jacobson@isgs.uiuc.edu

Maria Mastalerz, Indiana Geological Survey

Phone: 812-855-9416; mmastale@indiana.edu

William Andrews, Kentucky Geological Survey

Phone: 859-257-5500; wandrews@kgs.mm.uky.edu

Or

Jerry Weisenfluh, Kentucky Geological Survey

Phone: 859-257-5500; jerryw@kgs.mm.uky.edu

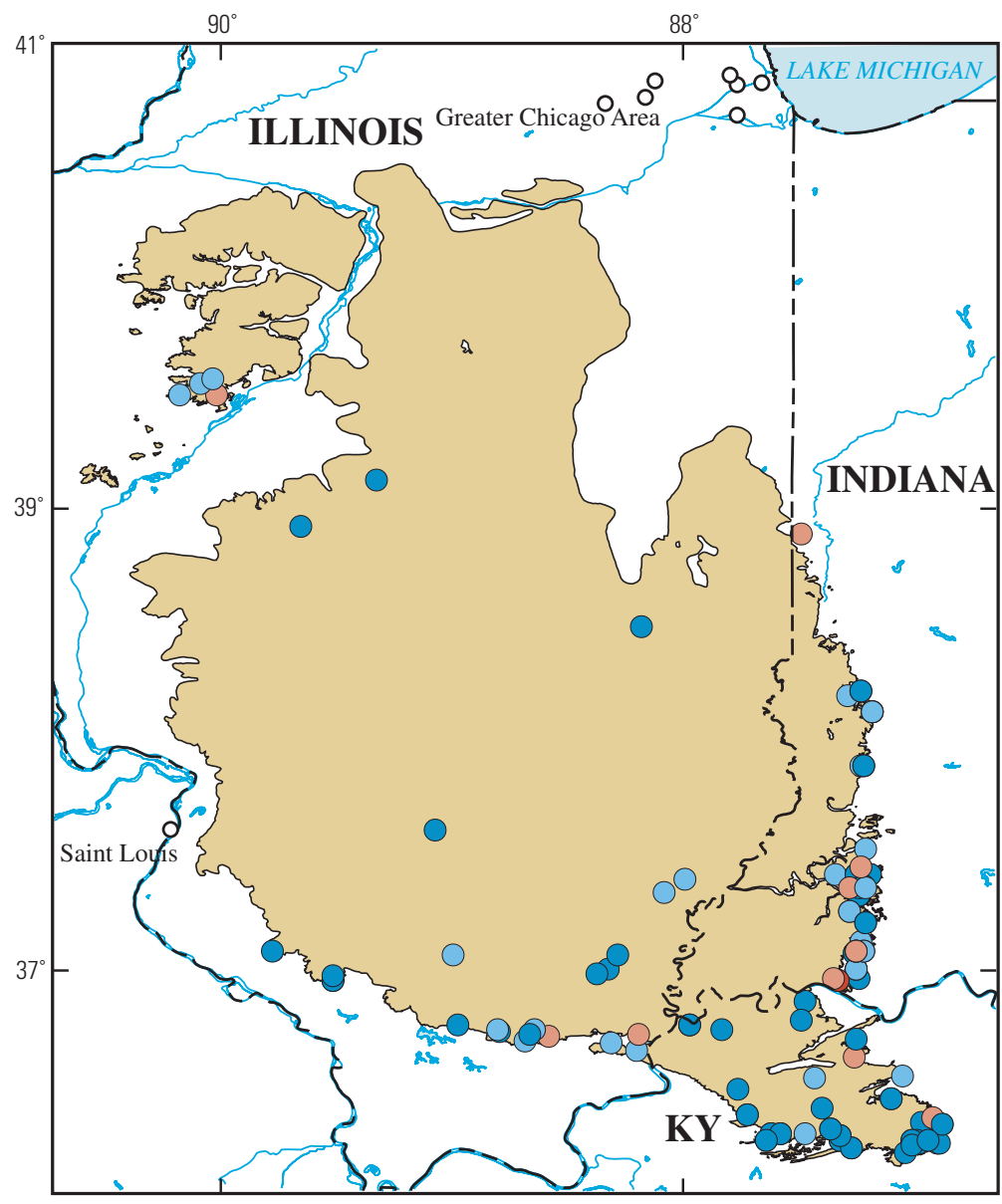

EXPLANATION

Mercury ppm

(whole-coal basis)

$0.01-0.1$

$0.1-0.22$

$0.22-0.47$

$0.47-1.2$

Springfield Coal extent

River, lake, or reservoir

Figure 4. Extent of the Springfield Coal in the Illinois Basin, localities of coal samples, and mercury contents (whole-coal basis). Modified from Hatch and Affolter (2002, Chapter E, Appendix 7, fig. 44).

\section{For further information on coal quality, contact:}

Ron Affolter, U.S. Geological Survey

Phone: 303-236-7752; affolter@usgs.gov

\section{For further information on GIS products, contact:}

Greg Gunther, U.S. Geological Survey

Phone: 303-236-5884; ggunther@usgs.gov 